\title{
The right to freedom of religion and the right against religious discrimination: Theoretical distinctions
}

\author{
Tarunabh Khaitan. * and Jane Calderwood Norton ${ }^{* *}$
}

This article argues that while they are often conflated, the right to freedom of religion and the right against religious discrimination are in fact distinct human rights. Religious freedom is best understood as protecting our interest in religious adherence (and non-adherence), understood from the committed perspective of the (non)adherent. This internal, committed, perspective generates a capacious and realistic conception of religious adherence, which reflects the staggering plurality of forms of religiosity (or lack thereof) as extant in contemporary societies. The right against religious discrimination is best understood as protecting our non-committal interest in the unsaddled membership of our religious group. Thus understood, the two rights have distinct normative rationales. Religious freedom is justified by the need to respect our decisional autonomy in matters of religious adherence. The prohibition on religious discrimination is justified by the need to reduce any significant (political, sociocultural, or material) advantage gaps between different religious groups. These differences reveal a complex map of two overlapping, but conceptually distinct, human rights which are not necessarily breached simultaneously.

\section{Introduction}

We live in a post-secular world where religion has made a surprising comeback, falsifying Weberian predictions of ever-continuing secularization. ${ }^{1}$ Almost every large society-some for the first time in recent history - is grappling with religious pluralism. At the same time, however, religious conflicts and religious terrorism occupy newspaper headlines, Islamophobia has become rampant, ${ }^{2}$. anti-Semitism has increased, and lower-scale religious hostility is rife. Even majority religions now view themselves as victims of secularization, multiculturalism, and the feminist and gay rights "agendas." The re-emergence of religion has resulted in at least some of these issues being debated in courts, using the legally prescribed discourse of human

\footnotetext{
* Professor of Public Law \& Legal Theory at Wadham College, Oxford and ARC Future Fellow at Melbourne Law School. Email: tarunabh.khaitan@law.ox.ac.uk.

${ }^{* *}$ Senior Lecturer, Faculty of Law, University of Auckland. Email: jane.norton@auckland.ac.nz.

For helpful comments, we thank several colleagues who, on editorial instructions, are too numerous to be named here. Special thanks to Sati Nagra for research support. Tarun Khaitan is grateful to New York University Law School, where he had the opportunity to work on the article as a Global Visiting Fellow. Usual disclaimers apply.

${ }^{1}$ Peter Berger, The Many Altars of Modernity: Towards a Paradigm for Religion in A Pluralist Age (2014); Suzanne Mancini \& Michel Rosenfeld, Constitutional SECUlarism in AN Age of Religious Revival xv-xvi (Mancini \& Rosenfeld eds., 2014) (referring to the "repoliticization of religion"). For an analysis as to the different strands of secularism see CÉCILE LABORDE, LIBERALISM’S RELIGION (2017).

${ }^{2}$ We find "Islamophobia" an inadequate term for capturing prejudice against Muslims, but we are sticking to it because it has acquired a certain currency.
} 
rights. Here, we most commonly see this debate take place in terms of the right to religious freedom or the right against religious discrimination.

This article is an intervention in an ongoing debate around the legal protection for religion. Some argue that the prohibition on religious discrimination has become a tool to protect prejudice and intolerance (usually against women, gays, bisexuals, lesbians, and transpersons), and therefore religion should lose its status as a protected characteristic altogether. ${ }^{3}$. By contrast, others argue that discrimination law is not taking conscience-based claims of religious adherents seriously enough and, in its zeal to protect gay people from discrimination, is itself discriminating against religious people, alongside violating their religious freedom. ${ }^{4}$. Therefore, this argument claims, human rights protection of religion is becoming increasingly toothless. It seems that neither side is happy with how the law deals with religion.

This article approaches the debate around law and religion from a different angle by arguing that, while they are often conflated, the right to freedom of religion and the right against religious discrimination are in fact distinct human rights. As such, they protect distinct human interests and distinct (although often overlapping) aspects of religion. Religious freedom is best understood as protecting our interest in religious (non)adherence. The right against religious discrimination is best understood as protecting our interest in the unsaddled membership of our religious group. ${ }^{5}$. One right is interested in protecting certain beliefs and practices, the other in protecting our tribe. The distinction is well-captured in the old joke about a Belfast rabbi being asked if he was "a Protestant Jew or a Catholic Jew." Or, as Ashis Nandy claimed in the Indian context, "Hindutva will be the end of Hinduism." ${ }^{6}$ In these examples, Protestantism/Catholicism/Hindutva identify sociopolitical group identities, whereas Judaism and Hinduism concern religious adherence. And yet, legal scholarship has paid little attention to this distinction or to its implications, ${ }^{7}$. and the courts have moved between the two rights with little explanation. ${ }^{8}$. In commenting on controversial issues involving religion, politicians

${ }^{3}$ Aileen McColgan, Class Wars? Religion and (In)equality in the Workplace, 38 InDUS. L.J. 1 (2009).

${ }^{4}$ Christopher McCrudden, Marriage Registrars, Same-Sex Relationships, and Religious Discrimination in the European Court of Human Rights (Queen's U. Belfast L. Res. Paper No. 2812289, July 2016), https://papers.ssrn.com/sol3/papers.cfm?abstract_id=2812289.

${ }^{5}$ By "unsaddled" membership we mean membership that does not incur external social, economic, cultural, or political costs. Religious adherence often demands compliance with the internal rules of the religion. That group members who are also adherents of that religion will be "saddled" with these internal rules is not of concern here.

${ }^{6}$ Ashis Nandy, The Twilight of Certitudes: Secularism, Hindu Nationalism and Other Masks of Deculturation, 1 PostColonial STUD. 283, 294 (1998).

${ }^{7}$ Honorable exceptions include Ronan McRea, Squaring the Circle: Can an Egalitarian and Individualistic Conception of Freedom of Religion or Belief Co-Exist with the Notion of Indirect Discrimination?, in FOUNDATIONS OF INDIRECT DisCRIMINATION LAW (Hugh Collins \& Tarunabh Khaitan eds., 2018); McCrudden, supra note 4. Also see the following article, which was published after this article had been finalised, and therefore our arguments could not benefit from its insights: Ilias Trispiotis, Religious Freedom and Religious Antidiscrimination, 82 MODERN LAW REVIEW 864 (2019).

${ }^{8}$ In the Eweida litigation (wearing of cross in private workplace), for example, the claim was brought as a religious discrimination case domestically (Eweida v. British Airways [2010] E.W.C.A. 80) and as a religious freedom case at the European Court of Human Rights (ECtHR) level (Eweida v. United Kingdom [2013] E.C.H.R. 37). Despite this change, there was no 
and the media have also perpetuated this lack of clarity.- ${ }^{9}$ This article attempts to remedy this oversight by setting out the distinction between the two sets of interests and their corresponding rights in conceptually clear terms. A subsequent article will canvass some of the key implications of these theoretical distinctions for legal doctrine and offer a normative restatement of the same.

Section 2 identifies and explains these two distinct religious interests. These interests may be distinguished by adopting different perspectives: religion as viewed from the committed perspective of the (non)adherent on the one hand and, on the other hand, the privileges and disadvantages that accompany the membership of a religious group as assessed from the non-committal (public) point of view. This distinction is important for two reasons. First, unpacking the differing facets of religious interests provides theoretical clarificationwhat is the law protecting when it protects religion? Second, the distinction has practical implications for how religious interests are protected (to be explored in a companion article). Section 3 identifies a key conceptual distinction between the two religious interests distinguished in the preceding section: religious adherence tracks the freedom to pursue the good, whereas unsaddled membership of a religious group directly tracks the good. Finally, in Section 4, we argue that, functionally, the right to religious freedom is best understood as protecting our interest in religious (non)adherence, whereas the right against religious discrimination is best understood as protecting religious group membership. We further argue-at a normative level - that the value of respecting decisional autonomy in matters of religious adherence underpins religious freedom, whereas the need to reduce the sociocultural and material advantage gaps between different religious groups is the key aim of the right against religious discrimination.

This distinction between religious adherence and religious group membership can help explain why it is not inconsistent for a person to disapprove of a religious group being made a target of prejudice, stereotypes, and social disadvantage, while at the same time rejecting or even condemning, some of the substantive religious beliefs of some such groups. It also explains why an uncommitted/non-adherent person can and should still receive antidiscrimination law's protection. The conceptual distinction we are proposing may not always be observed in the practice of a given jurisdiction. Lawyers often have strategic reasons to throw whatever argument might stick, and conceptual tidiness is often a casualty. It would be naive to expect theory and practice to mirror each other. Nonetheless, the conceptual (and normative) claims in this paper should be a useful guide to understanding the two rights that concern religion.

\section{Two distinct religious interests, from the committed and non-committal perspectives}

In this section, we identify two distinct interests we have with respect to religion: an interest in religious (non)adherence and an interest in our ability to enjoy unsaddled membership of a

acknowledgement, let alone explanation, of the distinction by the ECtHR. Moreover, the ECtHR applied religious freedom horizontally to the private employer (British Airways), in a similar manner to how religious discrimination law operates horizontally, with no discussion as to how this new development could be justified.

${ }^{9}$ For example, despite Eweida's claim in the ECtHR being grounded in religious freedom, David Cameron tweeted shortly after the decision that he was "[d]elighted that principle of wearing religious symbols at work has been upheld-people shouldn't suffer discrimination due to religious beliefs." See the reporting in "British woman wins discrimination case,"” Reuters, Jan. 14, 2013, available at https:/www.reuters.com/article/britain-religioncourt/british-woman-wins-religious-discrimination-case-idUSL6N0AJF9H20130115. 
religious group. To explore this distinction further, we distinguish the committed perspective of the religious (non)adherent from the noncommittal (public) identification of the privileges and disadvantages - social, economic, cultural, and political — that accompany the membership of (different) religious groups. The distinction grounds subsequent discussion about the nature of the two human rights concerning religion. While it is possible that some of our arguments could apply to non-religious interests also — such as adherence to a set of non-religious beliefs - this article's focus is on the legal protection of religion.

A word first about what is meant by religion. Religion is a complex and multifaceted intersubjective phenomenon, in the sense that its existence depends on its shared acceptance in the consciousness of several persons. Not all details of its contents need to be shared, but as a "social form," ${ }^{10}$ it cannot exist outside some shared consciousness within a social group. Other similar intersubjective phenomena include marriage (it will be meaningless to "marry" someone in a society where it did not exist as a social form), money (few would trade valuable goods for pieces of paper without an intersubjective acceptance of the value of these pieces of paper), and nations (imagined communities they might be, ${ }^{11}$ but a nation cannot be constituted in the imagination of one person-or, even ten, for that matter). This intersubjectivity requirement qualifies the committed perspective we are about to explore-it places constraints on what can count as religion, and more importantly what cannot (for example, my personal cult of bunny worship is not likely to satisfy the intersubjectivity requirement). ${ }^{12}$ Intersubjectivity, of course, admits to degrees - perhaps the traditional distinction between a religion and a cult (sans its more recent negative connotations) was based on the notion that cults are putative religions that do not (yet) satisfy the intersubjectivity threshold.

Beyond this, it is "notoriously difficult", and potentially problematic, to define religion. ${ }^{13}$. We will not attempt to do what our betters have been unable to do. Instead, we will satisfy ourselves with identifying the two distinct interests that people have in matters concerning religion: an interest in religious (non)adherence and an interest in the unsaddled membership of a religious group.

${ }^{10}$ Joseph Raz, The Morality of FreEdom 308-310 (1986). Raz understands social forms to be "forms of behaviour which are ... widely practised in society" or "common social forms of action." Social forms have "internal richness and complexity" and the degree to which a practice has to be shared, and by whom, are open questions. Raz is clear, however, that comprehensive personal goals_-such as, on our argument, religious (non)adherence — can only be founded in social forms. We assume, without argument, that atheism is a social form in most contemporary societies, although this is likely to be the case for many societies in the past too.

${ }^{11}$ BENEDICT ANDERSON, IMAGINED COMMUNITIES: REFLECTIONS ON THE ORIGIN AND SPREAD OF NATIONALISM (1983).

12 Maclure and Taylor, among others, also distinguish between "religious beliefs" and "expensive tastes," but on criteria other than intersubjectivity, see JOCELYN MACLURE \& CHARLES TAYLOR, SECULARISM AND FREEDOM OF CONSCIENCE 76 (2011).

${ }^{13}$ REX ADHAR AND IAN LEIGH, RELIGIOUS FREEDOM IN THE LIBERAL STATE 139 (2015). See also George C. Freeman, III, The Misguided Search for the Constitutional Definition of "Religion," 71 GEO. L.J. 1519 (1983), CAROLYN EVANS, FREEDOM OF RELIGION UNDER THE EUROPEAN CONVENTION ON HUMAN RIGHTS 51 (2001); Kent Greenawalt, Religion as a Concept in Constitutional Law, 72 CALIF. L. REV. 753 (1984); R (Williamson) v. Secretary of State for Education and Employment [2005] 2 A.C. 246 (HL) at [57]-[58]. 


\subsection{The committed interest in religious (non)adherence}

The committed or internal point of view is the point of view of the religious adherent. An adherent strives to believe in (what she thinks are) the tenets of her religion, and tries to practise (what in her view) it demands of her. From the committed perspective, in other words, religious adherence involves a commitment to some combination of a set of beliefs and practices. Our interest here is to describe briefly the phenomenon of religious adherence (and non-adherence) as it actually exists in most democracies. This must be the starting point of any account that seeks to understand the nature of our interest in religious (non)adherence. As such, we deliberately privilege this descriptive account of the committed adherent's perspective over any official doctrinal perspective of an authoritative religious body. In religions that have authoritative bodies - such as hierarchical churches - the official perspective of these bodies may well be reflected in that of many of its adherents. But adopting the official doctrinal perspective would be contrary to our goal of drawing up a realistic picture of religious (non)adherence that reflects the diversity between, and within, religions.. ${ }^{14}$

Before we proceed, there are two points on the prefix "non" before "adherents" may be noted. First, non-adhering belief and practice are important not only to atheists and agnostics but to all religious adherents. This is because adherents of a given religious tradition usually do so exclusively. In other words, their adherence to religion $\mathrm{X}$ often entails a rejection of all other religions, including (say) Y. Non-adherence is not restricted to matters of belief. Sometimes it demands performative non-participation in rituals or worship of other religions. Therefore, to take the committed perspective seriously we must recognize that for an adherent of $\mathrm{X}$, it may be important (for her adherence to X) not to believe in, or perform acts that are based on, the tenets of religion Y. For example, it may be important for an atheist or Jewish witness not to swear on the Christian Bible. Even in cases where the demands of another's religion entail an omission rather than an action-for example, non-Hindus required to refrain from eating beef - an interest in religious non-adherence is engaged if the prohibition on beefeating was premised on the Hindu injunction to treat the cow as sacred. In other words, all of us have an interest in religious non-adherence, whether we choose to assert it or not. More importantly, perhaps, non-adherence can, and usually does, arise out of religious commitment to the extent that adherence (to religion $\mathrm{X}$ ) usually entails non-adherence (to religion $\mathrm{Y}$ ).

The second point regarding non-adherence is that the line between the religious and the atheist is often drawn too sharply. In reality, not only are some religions atheistic (e.g. Jainism) or agnostic (e.g. some versions of Buddhism), others include the acceptance as well as the rejection of the divine within their ambit (e.g. Hinduism). ${ }^{15}$ Given the numerous ways in which religiosity manifests itself (consider, for example, those atheists who describe themselves as "spiritual"), sharp divisions between atheism and religiosity may capture the reality for some people but are unlikely to do so for everyone. ${ }^{16}$. For these reasons, our interest in religious

14 See Volkhard Krech et al., Religious Diversity and Religious Vitality: New Measuring Strategies and Empirical Evidence, 9 INTERDISC. J. RES. ON RELIGION 2 (2013); Lars Ahlin et al., Religious Diversity and Pluralism: Empirical Data and Theoretical Reflections from the Danish Pluralism Project, 27 J. ConTEMP. ReLIGION 403 (2012); Detlef Pollack, Religious Pluralism: Undermining or Reinforcing Religiosity?, 53 Soc’y 131 (2016).

${ }^{15}$ See generally Linda Woodhead, Intensified Religious Pluralism and De-differentiation: The British Example, 53 Soc’y 41 (2016). See also AMARTyA SEN, The ARgumENTATIVE Indian: WRITINGS ON INDIAN HISTORY, CULTURE AND IDENTITY 46 (2006) (Sen's recollection of a conversation with his grandfather, who identified the former's atheism as falling in the "Lokayata part of the Hindu spectrum").

${ }^{16}$ See RonALd DWORKIN, RELIGION WITHOUT God (2013). 
adherence must be understood to include an interest in non-adherence (jointly referred to as (non)adherence).

We can now turn to the first dimension of religious (non)adherence. The dimension of belief - or as the European Court of Human Rights prefers to call it, the forum internumentails (not) subscribing to certain fundamental beliefs (usually, but not necessarily) concerning the nature, origin, and character of life, especially focusing on the human condition and usually entailing views about improving it. This can include metaphysical views on life, pre-life, afterlife, and future lives, and the nature and existence of superhuman or non-human beings or powers as well as human ancestors. This is broadly consistent with what the UK Supreme Court recently referred to as "mankind's place in the universe and relationship with the infinite ... [which] may or may not involve belief in a supreme being." ${ }^{17}$. Characterizing this dimension of religion broadly in terms of "belief," rather than narrowly as "faith," allows religious traditions that invite belief without demanding faith to be included in the concept. It also encompasses those beliefs concerning god(s) and religion that are indifferent to, or even reject, faith or god (including versions of Buddhism, Jainism, atheism, and agnosticism).

Given this characterization of belief, one objection to our account of the committed perspective on religion might be that it is unrealistic, or, at least, not true for many adherents. The term "belief" can be read to overplay the thoughtfulness, consideration, and intensity that go into religious adherence. Many people simply (and one may say, unthinkingly) follow the (non)religion of their parents. ${ }^{18}$. Many others have a relaxed rather than intense, and flexible rather than dogmatic, approach to religious (non)adherence. Given our commitment to imbuing our conception of religious (non)adherence with the capaciousness that exists in practice, it would be odd if it included only the intense, inflexible, thoughtful, or single-minded (non)adherent. ${ }^{19}$. While our characterization of belief may not hold true for everyone, we take the seriousness and thoughtfulness that go into religious belief as a potentiality-realized to different degrees by different (non)adherents.

This potential for seriousness and thoughtfulness exists in those who reject religious adherence as much as in those who accept it. Some Christians rarely think about their Christianity, others arrive at it through deep contemplation, after rejecting the alternatives. Similarly, for some atheists, their atheism is merely a default (absence of) belief. For others, on the other hand, rejection of all (or some) religions is a deeply considered, strongly held, metaphysical and ethical belief fundamental to their individuality-some atheists are quite devout in their unbelief. The point is this: in the dimension of belief, religions make claims which have truth value (i.e. they are the sort of claims that may be true or false, or be true to some extent). This is why adherents are able to accept these claims as true. ${ }^{20}$. Accepting or rejecting these claims can both be thoughtful or thoughtless, salient or unimportant, intense or relaxed. With these caveats, we defend this capacious conception of religious belief, which

${ }^{17}$ R (Hodkin) v. Registrar General of Births, Deaths and Marriages [2013] U.K.S.C. 77 [57], [2014] A.C. 610 [57].

${ }^{18}$ See Farrah Ahmed, The Autonomy Rationale for Religious Freedom, 80 MoD. L. REV. 238 (2017).

${ }^{19}$ On a sociological index used to measure intensity of religiosity in persons, see Stefan Huber \& Odilo Huber, The Centrality of Religiosity Scale, 3 RELIGIONS 710 (2012).

${ }^{20}$ See Paul Horwitz, The Agnostic Age: Law, Religion, And the Constitution 153-154 (2011). 
adopts the committed (but not necessarily dogmatic) perspective of the adherent, because it most closely reflects the diversity of religious belief that exists in most contemporary societies.

The second dimension of religion, from the adherent's viewpoint, is its practical or performative side-its forum externum. This usually entails rules of behavior and performative practices such as worship, prayer, sacrifice, rituals, and meditation. The scope and demandingness of religious practice varies from religion to religion. Some religions also require that at least some of these practices and rituals must be undertaken in community with other adherents. Indeed, some practices and rituals can only take place where there is a religious community. ${ }^{21}$. Thus, the committed viewpoint often has a communal dimension. Some practical dimensions of religion follow from beliefs, often called manifestations of beliefs in European law, and provide reasons for action. But not all religious practice and performance can be characterized as manifestations of beliefs. Some religions (like Protestantism) emphasize beliefs, others (such as Buddhism and Orthodox Judaism) focus on practice, most on some combination of the two.. ${ }^{22}$.

We have seen how religious commitment is diverse. When we take the diversity of religious commitment seriously, we notice that most adherents subscribe to a web of multiple, but usually interrelated, beliefs and practices. Viewed from this committed perspective, the level of religious diversity one finds around the world is astonishing. Some religions seek coherence in their package of beliefs and practices. Others, like Hinduism, are happier to embrace mutually contradictory beliefs and practices. Even when not directly contradictory, there is significant interpretative latitude around religious demands on adherents. ${ }^{23}$. Even in religions with internal structures that make authoritative rulings on doctrinal disagreements, adherents often pick and choose from the packages on offer-the diversity of beliefs among Catholics on the legitimacy of same-sex marriages and abortion is a case in point. ${ }^{24}$. Indeed, a recent sociological study of "Catholics" in the UK shows that "if we measure Catholics by their conformity to some of the key beliefs and behaviors laid down by the Catholic magisterium ... only 5\% of Catholics qualify as 'faithful' or orthodox." ${ }^{25}$. Further still, adherents are often capable of giving varying weights and emphases to different religious demands, making the actual practice of religion staggeringly pluralistic. As the history of religious conflicts has shown, these differences could be over relatively small, and - for non-adherents and even some adherents of the same religion-inconsequential matters.

The committed interest in religious (non)adherence is expansive. It presents a picture of religious (non)adherence that is diverse and pluralistic (both within and between religions).

\footnotetext{
${ }^{21}$ See Farrah Ahmed \& Jane Calderwood Norton, Religious Tribunals, Religious Freedom, and Concern for Vulnerable Woman, 24 CHILD \& FAM. L. Q. 363, 377-378 (2012).

${ }^{22}$ It is for this reason that we use the capacious term "adherent" rather than the narrower term "believer" to describe a person committed to a religion.

23 This is why talk of Catholicisms, Islams, and Judaisms makes sense: Peter W. Edge, Determining Religion in English Courts, 1 OXFORD J. L. \& RELIGION 402, 402, 406 (2012); FARrah Ahmed, Religious Freedom Under the Personal LAW System 19-21 (2016).

24 Ayelet Shachar discusses this selectivity-or "forum shopping"-between state and religious institutions in the context of family law disputes: see AYELET SHACHAR, Multicultural JuRisDictions: Cultural DifFEREnCES AND WOMEn's Rights 122-126 (2001). John Bowen observed similar selectivity in relation to shari'a law in England: John Bowden, Private Arrangements "Recognizing Sharia" in England, Boston REV. (Mar./Apr. 2009), www.http://bostonreview.net/BR34.2/bowen.php.

${ }^{25}$ Woodhead, supra note 15 , at 42.
} 
This diversity exists in the dimensions of belief and practice. Religious commitment demands adherence as well as non-adherence from us. These expansive takes on our interest in (non)adherence are tempered, however, by the requirement of intersubjectivity. Intersubjectivity filters out highly eccentric and frivolous beliefs or practices. As such, the committed perspective avoids three potential pitfalls when defining the scope of the interest in religious (non)adherence: (i) overinclusion that leads to the protection of just about any ideology, belief, or practice; (ii) underinclusion of dissenting, minority, and heterodox religions; and (iii) exclusion of atheism and agnosticism. ${ }^{26}$. These findings are central to how we understand the right to freedom of religion, and the values that underpin it.

\subsection{The non-committal interest in unsaddled membership of a religious group}

Having considered religion from the committed perspective of the adherent, we now consider the phenomenon from a different angle by adopting an external or public perspective. This can be termed the non-committal perspective. From the non-committal, or public, perspective, we focus not on adherents of certain religions but on members of certain religious groups.

Group membership can affect how power and advantage are distributed in society. In most human societies, power and advantage — material, sociocultural, political—are distributed in ways that are sensitive to certain personal characteristics (such as race, educational attainment, or gender) but insensitive to other personal characteristics (such as zodiac signs, the number of letters in one's name, or one's favorite colour). ${ }^{27}$. Individual exceptions no doubt abound, but on a macro-level, these claims are generally accepted as true of many contemporary societies. Religious group membership, in most societies, tends to fall in the former category, inasmuch as it tends to affect the success of our lives (at least in the secular sense). Here, it does not matter whether a person actually adheres to the beliefs or practices of any particular religion. She is more likely than not to have powers and advantages (or lack thereof) in keeping with others who are, or are perceived to be, the members of the same religious group. She may belong to (or be perceived to belong to) a religious group, even without being an adherent. This (assumption of) membership may be because of the religious group membership of her parents, or because religious practice has become a familiar part of her cultural habits, or because she carries proxy characteristics (such as belonging to certain racial or ethnic groups) that signify (to others) adherence to a particular religion. She may even take pride in her membership of her religious group and find community and solace in fellow members despite not being an adherent, or she may dislike it, or be indifferent to it. Just like her membership of her caste or racial group, how she feels about it makes little difference to her actual or perceived religious group membership, just as her adherence or lack thereof makes no difference either. Like it or not, she is likely to be saddled with (or enjoy the privileges of) the (dis)advantages that accompany her membership of her religious group.

In most cases adherents are likely to be members of a religious group. However, the two categories do not entirely map onto each other. For example, recent converts may have cultural and ethnic traits that differ from most adherents. There are people who identify as "cultural Christians" or "atheistic Jews" having given up on adherence but not on the associated cultural traits. Heterodox and dissenting interpreters of a tradition-such as Reform Jews and Ahmadis - may be saddled with the cultural identification of majority adherents by the outside world but seen as non-members, or even heretics, by their "co-religionists.” It is not uncommon for Sikhs in North America and elsewhere to be taken to be Muslims because of racial and

\footnotetext{
${ }^{26}$ Andrew Koppelman, How Could Religious Liberty Be a Human Right? 16 InT’L J. Const. LAW 985 (2018).

${ }^{27}$ See TARUnABh Khaitan, A TheORy Of Discrimination LAW, ch. 2-3 (2015).
} 
cultural similarities. These examples illustrate that (non)membership of a religious group is not always within the control of the individual.

The non-committal perspective takes seriously the fact that religious group membership often gets mixed up with culture, ethnicity, race, language, and nationalityism. Not only is the (non)membership of her religious group not fully within the control of the individual adherent, she usually has even less control over the socio-political and material disabilities (or privileges) that accompany such membership. What is more, even for a typical religious adherent who fully embraces her actual and perceived religious group membership, her interest in being able to adhere truly to her religion is related to, but surely distinct from, her interest in her religious group not being subject to social, cultural, material or political disabilities.

Implicit in the preceding paragraphs is a very specific conception of a group.” The term is not necessarily used to refer to a cohesive collectivity with a shared culture/language/history/religion/identity, and so on. ${ }^{28}$. We have used the term "group" more loosely. It includes people who perceive themselves to be members of the group even when the group does not and those who are taken to be the members of the group when they do not see themselves as such. There need not be any cohesiveness to this group. On our understanding, "people with disabilities," heterosexuals, and yes, even atheists, qualify as a group. Having said that, given the non-committal perspective we have assumed, there needs to be some external, sociological, reality to the group, outside the internal point of view of its members. ${ }^{29}$

We have identified two interests pertaining to religion: the committed interest in religious (non)adherence and the non-committal interest in unsaddled membership of a religious group. These interests, we argue, are distinct. By way of illustration, a "Muslim" woman, living in a deprived, predominantly Muslim, neighborhood in Birmingham (or Delhi, for that matter) suffers because of such deprivation, whether or not she in fact adheres to any version of Islam. On the other hand, being forbidden from wearing a crucifix at work might engage a devout Christian's interest in religious adherence, but does not—in itself-affect his membership of his religious group (understood in the loose sense as explained above). We now turn to a key conceptual difference between these two interests.

\section{A conceptual distinction between the two interests}

We have identified two distinct interests a person might have with respect to religion: (i) an interest in her ability to (intersubjectively) determine and to pursue her religious commitments as a (non)adherent, and (ii) an interest in being unsaddled by the disabilities that accompany her religious group membership. Religion is not unique in possessing these two dimensions. Pregnancy, for example, has an internal dimension concerning a person's decision (as well as her ability to decide whether) to become (or not become) pregnant. From the non-committal perspective, on the other hand, pregnancy (and the ability or potential to become pregnant) brings with it certain social and economic costs, such as reduced attractiveness in the employment market, the stigma attached to pregnancy outside marriage, the medical and care costs associated with pregnancy, and so on. Sexual orientation has a similar quality. From the internal point of view, what matters is a person's orientation with respect to the sex and gender of the person they are sexually or romantically attracted to, and their decision (as well as their

\footnotetext{
${ }^{28}$ On this type of religious "group," see Renate Ysseldyk et al., Religiosity as Identity: Toward an Understanding of Religion From a Social Identity Perspective, 14 PERSONALITY \& SOC. PSYCHOL. REV. 60, 60-71 (2010).

${ }^{29}$ See also infra Section 4.1 (discussion toward the end of the section).
} 
ability to decide whether) to associate sexually and/or romantically with a person of the same sex as their own. Societally, this could have been completely irrelevant to the distribution of social, cultural, political, and material power between gay people and heterosexuals; unfortunately, as we know, this is not the case.

Defenders of pregnancy and sexual orientation rights have debated whether privacy or antidiscrimination is a better approach to defend these rights. ${ }^{30}$. These debates have taken place precisely because both approaches have something to offer to the protection of the interests involved. In this section, we draw upon these continuities to clarify a key conceptual distinction between the two categories of religious interests identified in the previous section. Unlike the debates that have taken place in the context of pregnancy and sexual orientation, however, we will show that these are not alternative ways of framing the same human interest, rather that they are two distinct interests that we ought to treat separately.

We draw a conceptual distinction between two sets of human interests: our interests in the good, and our interests in our freedom to pursue the good. In the first set, we have interests whose satisfaction is, at least prima facie, necessarily a good thing (from a public, objective, perspective). It may not be possible to always protect such interests all things considered, and some such compromises may be entirely legitimate. But on their own, the satisfaction of these interests is always a good thing. Such interests include our interest in adequate nutrition, good education, fair trial, protective shelter, and so on. In all these cases, the good is tracked directly by the satisfaction of the interest concerned.

On the other hand, we have interests not only in realizing the good but also (or, even especially) in pursuing the good on our own. In these cases, it is in our interest to freely define the good and to pursue it, even when we might sometimes make mistakes. ${ }^{31}$. Examples include our interest in freely choosing who to become friends with, whether and who to marry, what and how to say something, what career to pursue, whether and what films to watch or books to read, and so on. While, generally speaking, being free to pursue the good in such cases is a good thing, there is the possibility of making mistakes. Making friends with bullies, saying hurtful things simply to hurt others, or joining a racist organization do not become good simply because these acts were freely done. For this reason, the distinction between interests that directly track the good and those that track my interest in the freedom to define and to pursue the good makes sense. ${ }^{32}$. We do not, lest we are misunderstood, wish to suggest that our interests in the good are necessarily superior to our interests in our freedom to pursue the good. They are, nonetheless, conceptually different, and this difference could be normatively salient.

Now we can map this distinction onto the two interests we have identified. It is always a good thing that one's religious group is not saddled with relative social, political, and material disabilities. This is just a roundabout way of saying that social disabilities should not, in an ideal world, accompany religious group membership. On the other hand, our interest in religious adherence tracks our freedom to pursue the good in matters religious. The

${ }^{30}$ See Yoshino-Gerken debate: Heather Gerken, Larry and Lawrence, 42 TULSA L. REV. 843 (2008); Kenji Yoshino, Tribe, 42 Tulsa L. ReV 961 (2008). See also David Richards, Liberal Democracy and the Problems of Patriarchy, 46 IsRAEL L. REV. 169 (2013).

${ }^{31}$ Analogous to these interests are the rights that include the "right to do wrong": see Jeremy Waldron, A Right to Do Wrong, 92 ETHICs 21 (1981).

${ }^{32}$ Posner draws a similar distinction between intermediate/instrumental goods on the one hand and final/ultimate goods on the other: see Richard Posner, The Right to Privacy, 12 GA. L. REV. 393, 394 (1977). 
intersubjectively determined committed viewpoint is not, after all, subject to any public standard of reasonableness or morality, and may therefore make demands that are unreasonable or immoral. This key conceptual distinction underpins some of the normative judgments that need to be made in relation to the protection of these interests, especially in relation to their operation in horizontal relations between non-state actors.

\section{The right to freedom of religion and the right against religious discrimination:} functional and normative distinctions

Our starting point is that if most human rights documents recognize two distinct human rights pertaining to religion - the right to freedom of religion and the right against religious nondiscrimination - they are best understood as protecting distinct religious interests. The claim is conceptual and normative, rather than historical. Even if their distinct articulation is a historical accident, or even technical oversight on the part of the drafters, the conceptual claim would still be plausible in light of the distinctiveness of the two religious interests we identified in Section 2. Having identified these distinct interests, we will now argue that our interest in religious (non)adherence is best protected under the right to freedom of religion, and we are most likely to enjoy unsaddled religious group membership under a robust right against religious discrimination.

The main reason for this claim is that there are structural similarities between the interests identified in Section 2 and the jurisprudence concerning the two rights (at least in Europe). While there are other ways of reading legal doctrine concerning these rights, we select those strands in the jurisprudence that do the best job of protecting the two religious interests at stake. Thus, the interest and the right mutually define each other. We will argue that freedom of religion is valuable because it protects our decisional autonomy in matters of religious adherence. Freedom from discrimination based on certain protected characteristics matters morally because the possession of these characteristics tends to affect our access to those basic goods necessary for living a good life.

\subsection{The right to freedom of religion}

Freedom of religion is valuable because it protects our decisional autonomy in matters of religious adherence. Many other foundational values are also plausible, including the value of social goods such as religious tolerance, religious pluralism, and social harmony, and the value in respecting an individual's conscience or integrity. We do not deny that these values may also be good reasons to support some version of religious freedom. However, the only value that can fully support the capacious and realistic version of our interest in religious (non)adherence (as understood in Section 2) is the need to respect our decisional autonomy in matters pertaining to religious adherence.

Religious pluralism, harmony, and tolerance are no doubt valuable social goods, but they fail to directly underpin an individual's interest in religious (non)adherence (even though they may indirectly facilitate its protection in most circumstances). The historical origins of the protection of religious freedom may well lie in these social goods. ${ }^{33}$. Since its transformation into a contemporary human right, however, its underlying rationale must, at least primarily, be found in a fundamental human interest rather than in the common good. ${ }^{34}$

33 See Douglas Laycock, Religious Liberty as Liberty, 7 J. CONTEMP. LEGAL IsSUES 313, 317 (1996).

${ }^{34}$ R (Williamson) v. Secretary of State for Education and Employment [2005] 2 A.C. 246 (HL) at [22] (freedom of religion protects the subjective belief of an individual). 
The need to respect an individual's conscience is a more promising candidate. In fact, some scholars believe that religion is merely a placeholder for the protection of "conscience" in human rights law. ${ }^{35}$. While there might be very good reasons to protect conscience for its own sake, our account of religious adherence from the committed viewpoint shows that religion is both broader and narrower than conscience. Not all religious beliefs implicate one's conscience, which is typically other-regarding rather than self-regarding. For example, most people would accept that the religious obligations of Muslims to pray five times a day or make a pilgrimage are not matters of conscience. A belief that does not engage one's conscience may nonetheless be fundamentally important to the believer because it is demanded by his or her religion. On the other hand, not all conscientious beliefs are "religious." While many systemic and comprehensive world views, such as pacifism and environmentalism, could be sufficiently religion-like for certain purposes (and should perhaps be treated as such by human rights law), one's conscience can also make stand-alone demands against military service or eating animal products that do not flow from an existing commitment to any broader world view or involve intersubjectivity. For these reasons, the value of respecting an individual's conscience cannot ground the right to religious freedom.

Personal integrity is also insufficient to ground the right to religious freedom. This value takes an individual's relationship to herself seriously, and facilitates a harmonious and complete conception of one's self. It is related to conscience, but can encompass not only ethical but also performative and ritualistic (e.g. prayer and pilgrimage) dimensions of religious adherence. Like conscience, its scope is broader than religious adherence. However, overinclusion is less of a problem as long as we can carve out a clear subset of the value that concerns religion. We reject integrity as the foundational value of religious freedom not because it is overinclusive, but because it is also underinclusive-it does not include our capacious conception of a person's possible interests in religious adherence. Integrity tends to overvalue adherence that is intense, thought-through, and deeply held, and may fail to adequately protect religiosity that is relaxed, flexible, or habitual. Like conscience, it also has the tendency to cast religion in a particularly Protestant image ("Here I stand, I can do no other”), and may underserve other strands of religious (non)adherence. ${ }^{36}$

The value of respecting every person's decisional autonomy in matters of religious adherence is the most viable norm to underpin religious freedom. An autonomy-based rationale demands respect for a committed point of view in a way that other rationales may not. For example, a social harmony-based protection for religious freedom might be content to protect only the essential practices of major religions, interference in which might cause conflict. ${ }^{37}$. The autonomy rationale, on the other hand, is acutely sensitive to the religious pluralism and diversity we see in religious practice, including sensitivity to internal diversity within religions. It extends its protection to heterodox and dissenting views and to non-religious persons. One of us has argued elsewhere in some detail why the value of preserving our decisional autonomy in matters of religious adherence is also normatively attractive for other reasons. ${ }^{38}$. The underlying premises are that personal autonomy is of immense value to individuals, that in

\footnotetext{
${ }^{35}$ Michael Sandel, Religious Liberty_Freedom of Conscience or Freedom of Choice?, 3 UTAH L. REV. 597 (1989).

${ }^{36}$ This is not to suggest that there may not be some relationship between personal integrity and decisional autonomy more broadly; for example, it has been argued that autonomy may reflect or promote a person's integrity: e.g. RONALD DWORKIN, LIFE'S DOMINION 224 (1993); Ronald Dworkin, Autonomy and the Demented Self, 64 MilbanK Q. 1, 4-16. (1986).

37 The Indian Supreme Court tends to adopt this position.

38 JANE CALDERWOOD NORTON, FREEDOM OF RELIGIOUS ORGANIZATIONS (2016).
} 
order to be autonomous individuals must have access to a range of valuable opportunities, and that the freedom to make decisions in relation to (non)adherence to religions is one such valuable opportunity.. ${ }^{39}$

An autonomy-based rationale has the additional advantage of protecting our capacious interest in religious adherence: it is not underinclusive or unfair to non-believers. It also has significant support in case law. ${ }^{40}$ and academic literature. ${ }^{41}$. It is, of course, overinclusive, inasmuch as decisional autonomy in matters of religious adherence is a subset of our decisional autonomy generally. Even so, decisional autonomy in matters pertaining to religious (non)adherence is a clearly identifiable subset that protects a fundamental and valuable interest.

We do not claim that religion is the only, or the most valuable, subset of decisional autonomy. Other facets of decisional autonomy (e.g. in matters of sexual relationships) also need robust protection - as such, we sidestep the debate over whether religion is special except to express skepticism about the possibility.. ${ }^{42}$ Our skepticism is conceptual-attempts to define religion generally have failed because it is hard (if not impossible) to pin down a set of characteristics that pertain to all phenomena we agree to characterize as religions. Any effort to suggest that religion is special will necessarily need to highlight some common feature in all religions that makes religion special. The best that can be done is to imagine religion in a particular image-privileging a certain religious tradition and identifying its core features to claim special status. But that would be an argument for why Catholicism or Buddhism is special, not why religion is special. ${ }^{43}$

Two common criticisms of the decisional autonomy rationale must be responded to. The first is that religion is often not a matter of choice for its adherents. The second it that the rationale is too individualistic. With regard to the first criticism, autonomy is too easily

${ }^{39}$ On personal autonomy generally, see Raz, supra note 10.

${ }^{40}$ E.g. Jehovah's Witnesses of Moscow v. Russia, 53 Eur. H.R. Rep. 4 [134]-[135] (2011); Eweida v. British Airways Plc. [2010] E.W.C.A. Civ. 80 [40]; R (Begum) v. Governors of Denbigh High School [2006] U.K.H.L. 15, [2007] 1 A.C. 100 [93]; R (Williamson) v. Secretary of State for Education and Employment [2003] Q.B. 1300 (CA) (2003); Syndicat Northcrest v. Amselem, [2004] 2 S.C.R. 551 (Can.). For US examples, see LAURENCE TRIBE, AMERICAN CONSTitutional LAW 1284-1300 (2000); Kent GREENAWALt, RELigion AND The CONSTITUTION, Volume I: FREE EXERCise AND FAIRNESS 3-4 (2006). For a full account see Ahmed, supra note 18.

${ }^{41}$ E.g., Evans, supra note 13; GreENAWALt, supra note 40, at 3-4. Sandel also accepts that an autonomy-based conception of religious freedom is the predominant contemporary liberal understanding of religious freedom: Sandel, supra note 35, at 611 (1989). See also Ahmed, supra note 18, at 239.

${ }^{42}$ We take this debate to be concerned with whether religious interests are special-and weightier - than non-religious ones.

${ }^{43}$ See generally, Koppelman, supra note 26; Andrew Koppelman, Is It Fair to Give Religion Special Treatment?, U. ILL. L. REV. 571 (2006); Christopher Eisgruber \& Lawrence Sager, Does It Matter What Religion Is?, 84 NotRE DAME L. REV. 807 (2009); Micah Schwartzman, What if Religion Is Not Special?, 79 U. CHI. L. REV. 1351 (2012); BRIAN LEITER, WhY Tolerate Religion? (2012); Michael McConnell, Why Protect Religious Freedom?, 123 YALE L.J. 770 (2013). 
confused with a simplistic understanding of "choice." 44 . When we speak of "decisional autonomy" we do not intend to suggest that everyone necessarily has a free choice in matters of religious adherence. In fact, many adherents may not feel that they have (or, indeed, that they should have) any choice in subscribing to (what they view as) the truth. ${ }^{45}$. This truth may make many imperative demands on them that leave little room for choice. ${ }^{46}$. Others may have followed the religion of their parents with little thought and without ever consciously exercising any choice. Later in life, it may be psychologically very difficult for them to choose not to follow that religion. ${ }^{47}$

While we accept that an adherent may not feel she has a choice in religious matters, we are employing a capacious conception of autonomy. This conception seeks to protect the agent's moral capacity to make her own decisions on matters concerning religious (non)adherence, whether or not she feels she has (or in fact has) any "choice" in the matter and whether or not this moral capacity is ever acted upon. It protects the religious freedom of converts who actively change their religious status, of those who zealously reaffirm it, as well as those who never care to think much about it. This broad notion of decisional autonomy does not seek to relegate religious adherence to the private sphere either-it accepts that religious performance can and does have a public dimension. Nor does it reject communal dimensions of religious adherence-if communal performance matters to the adherent, it forms part of her decisional autonomy in religious matters.

Furthermore, the term "autonomy" is used here to mean an aspirational value that ought to be sought and realized, rather than entailing any descriptive claim about people actually possessing sufficient autonomy.. ${ }^{48}$. Of course some of us, in the descriptive sense, have more autonomy than others, and many don't have adequate autonomy. In the case of religion, it is no coincidence that most people adhere to the religions of their parents. Even so, there are good reasons for the state to take an adherent's self-proclaimed religious affiliation at face value in the absence of any proof of direct coercion, even if such adherence is deluded, irrational, unfairly influenced, and so on.. ${ }^{49}$. The autonomy loss resulting from the non-recognition or misrecognition of one's self-proclaimed religion is unlikely to be offset by any autonomy gains accruing from efforts by the state to help them "see light." The state telling me my religion might have got it wrong is usually better than it telling me I have got my religion wrong. An autonomy-based rationale dictates that we take the committed point of view of the adherent seriously. Individual decisional autonomy in religious matters would be left with little content if any external body or person could determine whether an individual has freely chosen to

44 The choice-based understanding of religious autonomy is rightly criticized. See RoNAN McCrea, Religion AND the Public ORder of the European Union 111 (2010). Similar criticisms apply to arguments from choice in the context of reproductive rights. See Thérèse Murphy, The Texture of Reproductive Technologies, in NEW TECHNOLOGIES AND HUMAN RigHTS (Thérèse Murphy ed., 2009).

${ }^{45}$ See Sandel, supra note 35, at 611; John Garvey, Free Exercise and the Value of Religious Liberty, 18 CONN. L. REV. 779, 791 (1986).

${ }^{46}$ See Nicholas Aroney, Individual, Community and State: Thoughts on Jane Norton, Freedom of Religious Organizations, (2017) 42 Australia J. LEGAL PHIL 270.

47 See Leslie Green, Rights of Exit, 4 LEgAL THEORY 165 (1998); Susan Moller Okin, "Mistresses of Their Own Destiny": Group Rights, Gender, and Realistic Rights of Exit, 112 ETHICs 205, 216-222 (2002).

${ }^{48}$ See generally Raz, supra note 10.

${ }^{49}$ R (Begum) v. Governors of Denbigh High School [2006] U.K.H.L. 15, [2007] 1 A.C. 100 [95]-[96]. 
adhere to a religion, what that religion is, what adherence to that religion entails, or who (if anyone) is an authority on what an adherence to that religion requires.

While the autonomy rationale takes the committed perspective of the adherent seriously, the rationale itself need not be endorsed as adequate justification for religious freedom from the committed point of view. It is not even clear, from the internal point of view of every religion, that the protection of (everyone's) religious freedom is valuable. It is only the content of the claim that the adherent seeks protection for that is discerned from the committed point of view; the reasons for protecting such claims (whether autonomy, toleration, or something else) need not be endorsed by the adherent's committed viewpoint. Nor is our argument that the law itself should adopt a committed viewpoint in matters of religion. We believe that the state's reasons must always seek to track public reasons, ${ }^{50}$. even as public reasons sometimes require the state to tolerate, respect, or protect actions grounded in sectarian reasons. Our argument here is simply that there may be good (public) reasons for the state to protect an adherent's committed internal perspective in matters of religion.

The second objection to the decisional autonomy rationale might be that it is too individualistic. We acknowledged, however, the importance of communal dimensions of religious practice in certain religions in the preceding section. While the rationale values the autonomy of individuals, it is compatible with - and even requires - the protection of any communal dimension of religious adherence. ${ }^{51}$. This will be the case as long as the collective or communal dimension is (intersubjectively as well as from the committed perspective) part of the religion. In other words, if communal worship is important to the individual's adherence to her religion, an autonomy-based rationale will protect it. Participation in the life of a religious community, or the acceptance of the religious authority of one's church, can therefore be aspects of religious adherence. ${ }^{52}$. Furthermore, the essence of religious practice itself often depends on social forms - i.e. forms of behavior which are widely practiced within that group. ${ }^{53}$. While it is individual believers who constitute a religious community, the group itself may have "a strong role to play in constructing individual religious affiliation." ${ }^{54}$. None of this needs to be denied by anyone who subscribes to the autonomy rationale for religious freedom. Any adherent who disagrees with such collectivity requirements is simply a dissenter within that group (whose right to dissent is equally protected). ${ }^{55}$. In other words, there surely are collective dimensions to freedom of religion, but these are derivative of the individual's right to that freedom. ${ }^{56}$

\subsection{The right against religious discrimination}

Unlike the right to freedom of religion, the right against religious discrimination is not a standalone guarantee. It is a species of the more general freedom from discrimination based on certain protected characteristics which, apart from religion, tend to be race, gender, disability, sexual orientation, language, ethnicity, and so on. As such, unless we have very good reasons

\footnotetext{
${ }^{50}$ Although the role of public reasons in Rawlsian philosophy is more limited than our claim above, on the concept of public reasons generally, see JOHN RAWLS, POLITICAL LIBERALISM $212 f$ (1996).

${ }^{51}$ See CALDERWOOD NORTON, supra note 38.

52 Hasan \& Chaush v. Bulgaria, 34 Eur. H.R. Rep. 55 [62] (2002).

${ }^{53}$ See RAZ, supra note 10, at 308.

${ }^{54}$ See CALDERWOOD NORTON, supra note 38, at 24.

55 See Green, supra note 47.

56 See Calderwood Norton, supra note 38. Cf. Julian Rivers, Religious Liberty as a Collective Right, in LAW AND RELIGION (Richard O’Dair \& Andrew Lewis eds., 2001).
} 
to think otherwise, the rationale for prohibiting religious discrimination must be found in the rationale for prohibiting discrimination more generally. ${ }^{57}$

The main function of the prohibition of discrimination, as one of us has argued before, is to prevent, reduce, or eliminate any substantial, abiding, and pervasive advantage gaps between certain cognate groups (i.e. groups defined by the same personal characteristic, such as men and women, or Christians and Sikhs). ${ }^{58}$. These advantage gaps could be political, material, or sociocultural, but they usually tend to manifest in all these dimensions simultaneously and reinforce each other. The underpinning normative argument is that we should care about such advantage gaps between groups because they reduce the ability of members of the (relatively) disadvantaged groups to access certain basic goods-negative freedom, an adequate range of valuable opportunities, and self-respect-whose secure enjoyment is essential to our ability to live a free and flourishing life. ${ }^{59}$. Thus, even though the object of discrimination law's immediate attention is groups, in keeping with the contemporary human rights tradition, the ultimate commitment is to the freedom and well-being of (all) individuals. ${ }^{60}$

One need not accept the details of this rationale for discrimination law. But almost all credible accounts of this area of law-at least accounts that take the Anglo-American law concerning the regulation of discrimination seriously-accept that the current or historical disadvantage faced by social groups lies at the heart of discrimination law. This is true of egalitarian accounts, ${ }^{61}$ freedom-based accounts, ${ }^{62}$ as well as expressive accounts ${ }^{63}$. that seek to explain discrimination law. Given this consensus - at least at a broad level—it would be very surprising if the main purpose of the law regulating religious discrimination was to protect individual religious (non)adherence (rather than to secure an unsaddled membership of one's religious group). This theoretical consensus over the group focus in discrimination law may seem surprising to some practitioners, especially if they notice that typically, the claimants in discrimination law are individuals, and that the protection is offered symmetrically to both the advantaged and the disadvantaged groups. To answer this objection, we need to distinguish this systemic-functional claim about the overall purpose of discrimination law from specific design issues. Drawing upon Rawls and Hart, one of us has argued elsewhere that full transparency between the functional goal of discrimination law and the design of particular rules that regulate discrimination may actually be counterproductive. ${ }^{64}$. To put the point differently, the goal of reducing relative group disadvantage may be ill-served if courts start asking in each case what outcome will best reduce such disadvantage. Additional

57 See generally Dworkin on local priority within 'departments' of law: RONALD DwORKIN, LAW's EMPIRE 250f (1986).

${ }^{58}$ See KHAITAN, supra note 27. For comparable accounts see Owen Fiss, Groups and the Equal Protection Clause, 5 PhIL. \& Pub. Aff. (1976); Cass Sunstein, The Anticaste Principle, 92 MiCH. L. REV. 2410 (1994).

${ }^{59}$ On how this happens, see KHAITAN, supra note 27, ch. 5.

${ }^{60}$ See Khaitan, supra note 27, at 38f (on the "eccentric distribution condition" for more clarification on the group orientation of discrimination law).

${ }^{61}$ See, e.g., SANDRA FREDMAN, DisCRIMINATION LAW (2002); Catharine MacKinnon, Toward a Renewed Equal Rights Amendment: Now More than Ever, 37 HARV. J. L. \& GENDER 569 (2014).

${ }^{62}$ See, e.g., Sophia Moreau, What Is Discrimination?, 38 PHIL. \& PUB. AfF. (2010); KHAITAN, supra note 27.

${ }^{63}$ See, e.g., Deborah Hellman, When is DisCRimination Wrong? (2008).

${ }^{64}$ See KHAITAN, supra note 27, at 9f. 
considerations of fairness, pragmatism, clarity, certainty, and a normative commitment to liberalism also inform the design of antidiscrimination rules. Considerations such as these, for example, dictate that (in general) discrimination law should protect not only the relatively disadvantaged group but also its cognate advantaged groups. ${ }^{65}$

On the reading we have outlined, non-committal religious group membership, rather than committed religious adherence, lies at the heart of discrimination law. ${ }^{66}$. Because religion is one of the characteristics that creates substantial, abiding, and pervasive advantage gaps between cognate groups, it is a protected characteristic in discrimination law, alongside race, sex, sexual orientation, disability, pregnancy, ethnicity, and other such characteristics. It follows that the big-picture concern of discrimination law is to prevent or mitigate a caste-like organization of society on religious lines where certain religious groups end up with a lower class status. Burdening adherence to a particular religion may well increase the (political, material, social) advantage gap between religious groups, but there are other ways this can happen too. It may be, for example, that most members of a minority religion are poor, or that they are recent immigrants, or that they are subject to widespread hostility and ostracism by the majority religious group because of their racial difference, and therefore suffer relative group disadvantage. Discrimination law is indifferent to the cause of such disadvantage. Rather, it is the fact or likelihood of relative group disadvantage that this area of law seeks to counter.

As we move from the systemic concern that discrimination law has with group disadvantage to specific design issues, we notice-at least outside the context of religious discrimination - a rather tightly regulated scope of what counts as discrimination. In the limited contexts that discrimination law regulates, a claimant must establish a prima facie case of direct or indirect discrimination against her. The determination is objective, and requires the claimant to show either that she suffered some non-remote adverse effect:

(a) because of the defendant's intentional reliance on a protected characteristic, ${ }_{-}^{67}$ or

(b) that the defendant's facially neutral policy had such adverse effect

i. either exclusively on members of her group, ${ }^{68}$ or

ii. on those who disproportionately belong to her group. ${ }^{69}$

British law treats (a) and (b)(i) as instances of direct discrimination, and (b)(ii) as a case of indirect discrimination. Cases in (a) that involve the intentional targeting of a religious group, or even the intentional use of religion in a decision, tend to be rare and, when they come up, tend to be easier to decide. It is the set of cases in (b) that are the most controversial and shall be our focus in the discussion that follows. These cases involve the impact of a facially neutral

\footnotetext{
${ }^{65}$ See id., ch. 6.

${ }^{66}$ Just as the protected characteristic "sex" is akin to the personal characteristic of sex and gender rather than sexual intercourse. Of course, group membership and behavior are related, but not reducible to each other.

${ }^{67}$ British/European law treats this as direct discrimination: Bougnaoui v. Micropole SA (2017) Case C-188/15 (E.C.J.). Even these cases that track intentional use of a protected characteristic as a basis of classification are ultimately concerned with the adverse effect of such use on the protected group. See KHAITAN, supra note 27, ch. 6.

${ }^{68}$ This is also direct discrimination in British/European law. See James v. Eastleigh B.C. [1990]

2 A.C. 751; Bull v. Hall [2013] U.K.S.C. 73.

${ }^{69}$ This alone is indirect discrimination in British/European law. See Essop v. Home Office (UK Border Agency) [2017] U.K.S.C. 27.
} 
policy on the claimant's group. In such group impact cases, discrimination must be established by showing comparative adverse effect on the claimant's group, in relation to a cognate group. So, in the case of religion, a claimant must show that the policy in question not only affected her but also that it (exclusively or disproportionately) affected other members of her religious group when compared with some other cognate group. For example, a Muslim claimant will need to show that an employer who requires a university degree for a manual job in an area where Muslims are disproportionately less likely to have university degrees affected not just her (as a potential applicant who did not meet the criterion) but also disproportionately affected Muslims (in that area) generally.

Whether a protected group suffered adverse impact is determined objectively, rather than subjectively. This objective standard sets a relatively high bar for making a prima facie case of discrimination. This high bar is unavoidable, to some extent, given that discrimination law's primary concern is with group disadvantage. While the entry threshold is relatively high, however, the possibility of justifying a successful prima facie case is relatively slim. Direct discrimination admits to very few and very high threshold exceptions. Moreover, even though indirect discrimination can be justified, certain types of justifications-such as the business profitability, consumer preference, or competitive disadvantage-are typically barred. Although the claimant has a demanding threshold to cross in order to make a prima facie case of discrimination, once she has met this threshold the possibility that the discrimination she faces might be justified is slim and usually assessed strictly by courts.

Religious group membership (chosen or otherwise) saddles us with privileges and disabilities. Given this, something would be lost (and very little gained) if the right against religious discrimination was reduced to just another means of protecting our interest in religious adherence. While there may be good strategic reasons for practicing lawyers to try to achieve these outcomes, the erasure of the distinction we are hoping to highlight will not only create conceptual confusion but will ultimately be a bad thing for the protection of our religious interests.

We should emphasize that the sharp distinction we are drawing between the two rationales for human rights protection of religious interests - religion as adherence and religion as group membership-is a conceptual one. The two religious interests can, after all, overlap. It is evidently true that often protection of religious freedom is likely to reduce not just the religious but also social, material, and political disadvantages faced by its adherents. And sometimes discrimination against members of a group will also impinge upon religious adherence. In fact, if we map all cases of breaches of the right to religious freedom and all cases of breaches of the right against religious discrimination, the overlap might indeed be significant. This does nothing, however, to minimize the existence or significance of the conceptual and normative distinctions we are trying to draw out. Our argument is that it is not the purpose of discrimination law to secure religious freedom, nor is it the purpose of the right to religious freedom to reduce religious group disadvantage.

\section{Conclusion}

This article makes a contribution to ongoing theoretical debates around the legal protection of religion. In these debates, the right to freedom of religion and the right against religious discrimination are often conflated and little attention has been paid to their conceptual and normative differences. This article has argued that they are in fact distinct human rights. As 
such, they protect distinct human interests and distinct aspects of religion. Religious freedom is concerned with protecting an interest in our ability to (not) adhere to our religious commitments. The right against religious discrimination is concerned with a separate interest in ensuring that our religious group does not suffer relative sociocultural, political, or material disabilities in comparison with other religious groups. This article brings conceptual clarity to this area and helps explain what the law is protecting when it protects religion. Key doctrinal implications follow for the respective scope of the two rights, whether they may be claimed against non-state actors, and their divergent assessment of religious establishment. In a followup article to be published in the next issue of this journal, we will offer a normative restatement of the legal doctrine relating to these rights. In particular, we will map these implications in relation to their scope, horizontal application and religious establishment, and also outline the resulting areas of overlap and differences between the two legal rights. 


\section{University Library}

\section{- M M N E R VA A gateway to Melbourne's research publications}

Minerva Access is the Institutional Repository of The University of Melbourne

Author/s:

Khaitan, T;Calderwood Norton, J

Title:

The Right to Freedom of Religion and the Right Against Religious Discrimination: Theoretical Distinctions

Date:

2019

Citation:

Khaitan, T. \& Calderwood Norton, J. (2019). The Right to Freedom of Religion and the Right Against Religious Discrimination: Theoretical Distinctions. International Journal of Constitutional Law, 17 (4), pp.1125-1145. https://doi.org/10.1093/icon/moz087.

Persistent Link:

http://hdl.handle.net/11343/242041 